\title{
Perlindungan terhadap inventor terkait unsur kebaruan paten yang hapus akibat tidak membayar biaya tahunan
}

\author{
Moza Ramadhani ${ }^{1}$, Muhammad Amirulloh ${ }^{2}$, Pupung Faisal ${ }^{3}$
}

${ }^{1}$ Moza Ramadhani; Fakultas Hukum Universitas Padjajaran; Jalan Raya Bandung Sumedang KM-21 Jatinangor; Sumedang; 45363; Jawa Barat; Indonesia.

${ }^{2}$ Muhammad Amirulloh; Fakultas Hukum Universitas Padjajaran; Jalan Raya Bandung Sumedang KM- 21 Jatinangor; Sumedang; 45363; Jawa Barat; Indonesia.

${ }^{3}$ Pupung Faisal; Fakultas Hukum Universitas Padjajaran; Jalan Raya Bandung Sumedang KM-21 Jatinangor; Sumedang; 45363; Jawa Barat; Indonesia.

\begin{tabular}{l}
\hline A R T I C L E I N F O \\
\hline Article history: \\
Received 2021-01-05 \\
Received in revised form \\
2021-03-25 \\
Accepted 2021-04-01 \\
\hline
\end{tabular}

Kata kunci:

Paten; Unsur Kebaruan; Invensi; Biaya Tahunan Paten.

\section{Keywords:}

Patens; Novelties; Inventions; Patent Annual Fees.

DOI: https://doi.org/10.26905/ idjch.v12i1.4717.

\section{How to cite item:}

Ramadhani, M., Amirulloh, M., \& Faisal, P. (2021).

Perlindungan terhadap inventor terkait unsur kebaruan paten yang hapus akibat tidak membayar biaya tahunan. Jurnal Cakrawala Hukum, 12(1). 51-59. doi:10.26905/ idjch.v12i1.4717.

Corresponding Author:

* Moza Ramadhani.

E-mail address: mozarmdhni@gmail.com.

\begin{abstract}
Abstrak
Dihapuskannya paten yang telah terdaftar menyebabkan hak eksklusif yang dimiliki inventor untuk menggunakan invensinya akan menjadi hilang, hal tersebut menyebabkan kerugian bagi inventor akibat tidak dapat menggunakan invensinya kembali. Selain itu, inventor juga kehilangan hak ekonomi terhadap paten tersebut akibat tidak dapat menggunakan invensinya. Pengaturan mengenai dihapuskannya paten yang diatur dalam Pasal 130 hurufd UU Paten dinilai belum memberikan perlindungan yang memadai bagi inventor. Berdasarkan hal tersebut tujuan penelitian ini ialah untuk menentukan kualifikasi hukum perbuatan Direktorat Paten dalam menghapsukan paten yang telah terdaftar serta menentukan tindakan hukum yang sebaiknya dilakukan oleh inventor untuk mendapatkan patennya kembali. Dalam penelitian, metode yang digunakan adalah yuridis normatif, dan spesifikasi penelitian deskriptif-analitis. Tujuannya untuk melakukan analisis terkait peraturan perundang-undangan yang berlaku dan teori hukum dengan praktik pelaksanaan dalam kenyataan. Data dikumpulkan melalui studi pustaka dan studi lapangan, kemudian dianalisis dengan metode normatif kualitatif. Hasil akhir penelitian menyatakan bahwa dihapuskannya paten akibat tidak membayar biaya tahunan dan membuat paten menjadi public domain sebagaimana Pasal 130 huruf d UU Paten bertentangan dengan Prinsip Alter Ego karna dengan dihapuskannya paten tersebut membuat paten berubah menjadi public domain dan menunjukan bahwa paten tersebut telah kehilangan unsur kebaruannya.
\end{abstract}

\section{Abstract}

The elimination of a registered patent causes the inventor's exclusive right to use his invention to be lost, it causes losses to the inventor as a result of not being able to reuse the invention. In addition, the inventor also loses economic rights to the patent 


\section{Jurnal Cakrawala Hukum, Volume 12 No. 1 April 2021}

ISSN PRINT 2356-4962 ISSN ONLINE 2598-6538

because he cannot use his invention. The regulation regarding the abolition of patents stipulated in Article 130 letter d of the Patent Law is deemed not to provide adequate protection for inventors. Based on this, the aim of this research is to determine the legal qualifications of the Patents Directorate's actions in consuming registered patents and to determine the legal actions that should be taken by inventors to get their patents back. In research, the method used is normative juridical, and descriptive-analytical research specifications. The aim is to analyze the prevailing laws and regulations and legal theory with practical implementation in reality. Data were collected through literature and field studies, then analyzed using qualitative normative methods. The final result of the research states that the elimination of patents is due to not paying annual fees and making the patent into the public domain as in Article 130 letter d of the Patent Law is against the Alter Ego Principle because the elimination of the patent makes the patent turn into the public domain and shows that the patent has lost its novelty element.

\section{Pendahuluan}

Perkembangan teknologi di setiap negara senantiasa tidak terlepas dari timbulnya invensi atau ciptaan-ciptaan baru maupun kreatifitas di berbagai bidang atas hasil pemikiran manusia. Setiap hasil karya intelektual manusia perlu untuk mendapatkan pelindungan hukum yang mana hal tersebut merupakan bentuk penghargaaan atas karya intelektual yang telah diciptakan. HKI itu sendiri merupakan hak yang berkenaan dengan kekayaan yang timbul karena kemampuan intelektual manusia (Ahkam, 2005). Hak atas kekayaan intelektual sebenarnya merupakan bagian dari benda, yaitu benda tidak berwujud (benda immaterial) (Saidin, 2010). Hak kekayaan intelektual adalah salah satu sumber daya yang memiliki nilai ekonomi bagi pemilik haknya apabila didaftarkan dan digunakan secara professional (Ranitya, 2020).

Dilihat dari lahirnya HKI, hak ini masih belum lama memperoleh pelindungan hukum, baik pengaturannya di negara-negara maju maupun di negara berkembang (Syahmin, 2007). Pelindungan terhadap HKI sangat penting untuk diberikan agar inventor tetap memiliki keinginan untuk meghasilkan karya intelektual sebanyak-banyaknya bagi kemajuan peradaban manusia. Indonesia termasuk salah satu negara yang masih minim dalam menerapkan pelindungan terhadap kekayaan intelektual sehingga mengakibatkan banyaknya kekayaan intelektual milik masyarakat dan bangsa Indonesia diambil dan dimanfaatkan bahkan memberikan keuntungan ekonomi bagi negara lain. Pelindungan tersebut dimaksud agar pemilik HKI baik perorangan, kelompok atau badan usaha dapat menggunakan haknya atau mengeksplorasi kekayaannya dengan aman yang pada gilirannya dapat menciptakan iklim ekonomi dari hasil yang dikaryakannya dan dapat menciptakan iklim ekonomi juga bagi negara serta dapat memberikan manfaat dan kesejahteraan bagi bangsanya karena adanya pelindungan. Pemerintah memberikan pelindungan dengan turut serta melakukan implementasi bagi masyarakat termasuk instansiinstansi dan perguruan tinggi yang berada diseluruh Indonesia yang menangani bidang HKI.

Sebelum suatu HKI dapat dilindungi, maka kekayaan intelektual tersebut harus didaftarkan terlebih dahulu. Dengan dilakukannya pendaftaran pada HKI maka negara memberikan pelindungan kepada orang yang memenuhi persyaratan untuk mendaftar, dan akan memberikan hak ekslusif kepada orang yang telah berhasil melakukan pendaftaran. Pelindungan yang dimaksud berupa penerimaan hak ekslusif yang bersifat monopoli untuk waktu tertentu dan hanya dimiliki oleh or- 


\section{Perlindungan terhadap inventor terkait unsur kebaruan paten yang hapus akibat tidak membayar biaya tahunan}

Moza Ramadhani, Muhammad Amirulloh, Pupung Faisal

ang yang terkait langsung dengan kekayaan intelektual yang didaftarkan tersebut. Melalui hak ekslusif pemilik HKI dapat mencegah orang lain untuk membuat, menggunakan atau berbuat sesuatu terhadap HKI tersebut tanpa izin. Indonesia sendiri menganut sistem first to file dalam bidang Paten, yang mana sebaiknya permohonan paten diajukan secepat mungkin dengan memperhatikan syarat-syarat paten yaitu invensi bersifat baru dan mengandung langkah inventif serta dapat diterapkan dalam industri. Jika suatu paten sudah didaftarkan, maka paten itu sendiri memiliki hak esklusif, yaitu hak ekonomi untuk memperoleh keuntungan finansial dari perolehan pengakuan HKI berupa pengalihan dan pemberian izin penggunaan HKInya dengan memperoleh royalti serta hak moral yang selalu melekat atas diri inventor atau pemegang paten.

Dalam hal ini, pembahasan hak kekayaan intelektual mengenai paten. Pelindungan hukum paten untuk invensi yang sudah didaftarkan diberi jangka waktu selama 20 (dua puluh) tahun untuk paten biasa dan 10 (sepuluh) tahun untuk paten sederhana. Selama jangka waktu tersebut inventor dapat melaksanakan sendiri invensinya ataupun menyerahkan kepada orang lain untuk melaksanakannya. Paten itu sendiri merupakan hak kebendaan yang dapat beralih ataupun dialihkan baik seluruh maupun sebagian.

Pelindungan paten di negara pada umumnya mensyaratkan bahwa pelindungan paten, hanya diberikan kepada, Invensi yang baru (novelty), Mengandung langkah inventif (inventive step), Dapat diterapkan dalam industri (industrial applicability). Perkembangan aturan mengenai paten termasuk juga di dalamnya pengaturan mengenai penghapusan pada paten itu sendiri. Penghapusan paten merupakan salah satu bentuk penegakan hukum yang disebabkan oleh invensi yang diberi paten tidak layak mendapatkan paten atau pemilik paten tidak melaksanakan kewajibannya terhadap paten yang sudah terdaftar. Berdasarkan Pasal 130 UU Paten, penghapusan paten yang telah terdaftar dapat dilakukan dengan empat hal, yaitu: permohonan penghapusan dari pemegang paten, putusan pengadilan yang menghapuskan paten, putusan penghapusan paten yang dikeluarkan oleh komisi banding paten, atau karena pemegang paten tidak memenuhi kewajiban membayar biaya tahunan.

Mengenai pengahapusan paten akibat tidak memenuhi kewajiban membayar biaya tahunan yang diatur dalam Pasal 130 huruf d UU Paten, seharusnya tidak dapat semerta-merta menghapuskan Hak Paten yang telah dimiliki oleh inventor karena kita ketahui biaya tahunan tersebut merupakan hal yang bersifat administratif, yang mana hal administratif tersebut tidak dapat menghapuskan hal yang bersifat subtantif.

Dihapuskannya paten yang telah terdaftar menyebabkan hak eksklusif yang dimiliki inventor atau pemegang paten untuk menggunakan invensinya akan menjadi hilang, maka hal tersebut menyebabkan kerugian bagi inventor akibat tidak dapat menggunakan invensinya kembali. Selain itu, inventor juga kehilangan hak ekonomi terhadap paten tersebut akibat tidak dapat menikmati atau menggunakan invensinya. Dengan demikian hal ini tentu sangat penting untuk dibahas dan diteliti lebih lanjut, karena dampaknya yang cukup besar bagi kepastian hukum para pemegang hak paten.

\section{Metode Penelitian}

Penelitian ini adalah penelitian yuridis normatif, dengan menggunakan bahan pustaka yang terdiri dari: (1) Norma dan kaidah, peraturan dasar, serta peraturan perundang-undangan sebagai bahan hukum primer; dan (2) Bahan hukum yang memberi penjelasan terhadap bahan hukum primer seperti pendapat ahli, buku-buku atau karya ilmiah lain yang ditulis oleh ahli hukum, serta hasil karya ilmiah beberapa sarjana sebagai bahan hukum sekunder. Pengambilan data dilakukan dengan studi pustaka dari buku, jurnal ilmiah, hasil dari penelitian serta peraturan perundang-undangan terkait, juga dengan melakukan penelitian lapangan 


\section{Jurnal Cakrawala Hukum, Volume 12 No. 1 April 2021}

ISSN PRINT 2356-4962 ISSN ONLINE 2598-6538

melalui wawancara dan pengamatan langsung dengan narasumber. Dalam menjawab rumusan masalah dalam penelitian, analisis data dilakukan dengan cara deskriptif kualitatif.

\section{Pembahasan}

Seperti halnya hak kekayaan intelektual lainnya, paten adalah bentuk properti individu yang bisa juga dimiliki, dijual, dilisensikan, dan ditransfer baik oleh individu maupun oleh badan atau lembaga. Pada sertifikat paten nama individu penemu atau inventor tetap dituliskan, meskipun kemudian hak dari penguasaan paten tersebut dimiliki oleh orang lain. Pada dasarnya prinsip hukum paten adalah memberikan hak paten berupa hak eksklusif yang diberikan kepada inventor atas hasil invensinya tersebut. Hak Paten memiliki hak eksklusif yang diberikan oleh negara kepada pemilik hak paten atas hasil invensinya di bidang teknologi.

Hak Paten memiliki hak eksklusif yang diberikan oleh negara kepada pemilik hak paten atas hasil invensinya di bidang teknologi. Hak eksklusif tersebut baru diberikan kepada pemilik paten ketika paten tersebut sudah memenuhi persyaratan patentabilitasnya, yakni baru, mengandung langkah inventif, serta dapat diterapkan dalam industri, kemudian didaftarkan ke Direktorat Jenderal Kekayaan Intelektual (Mardiana, 2020). Hak eksklusif tersebut baru diberikan kepada pemilik paten ketika paten tersebut sudah memenuhi persyaratan patentabilitasnya, yakni baru, mengandung langkah invenetif, serta dapat diterapkan dalam industri (Amirulloh, 2016).

Dengan diberikannya hak eksklusif paten kepada inventor oleh negara selama 20 (dua puluh) tahun, menyebabkan inventor berhak untuk melarang pihak lain memanfaatkannya dalam bentuk apapun tanpa persetujuannya. Hal ini merupakan keuntungan besar dalam dunia industri terutama teknologi informasi yang terus menerus berkembang, karena dengan memanfaatkan tek- nologi yang telah dipatenkan dan dengan demikian dilindungi oleh hukum, paten merupakan aset tidak berwujud (intangible asset) yang memiliki nilai ekonomi yang luar biasa besar karena hanya pemegang paten sajalah yang berhak memanfaatknnya selama 20 tahun tanpa gangguan yang berarti setiap produk, metode, atau proses yang dimiliki oleh pemegang paten menjadi unik dan memiliki keunggulan yang tidak dimiliki oleh pesaingnya.

Berdasarkan hasil wawancara oleh salah satu staff Direktorat Paten Kementerian Hukum dan HAM (Karisman, 2020) yang menangani kasus Paten yang dihapuskan akibat tidak membayar biaya tahunan dijelaskan bahwa jika suatu paten yang telah dihapuskan dari daftar umum paten harus memiliki unsur kebaruan dari paten yang sebelumnya telah didaftarkan, karena jika suatu paten dihapuskan dari daftar umum paten, paten tersebut sudah berubah menjadi public domain dan siapapun bebas untuk menggunakannya, yang mana hal tersebut tidak lagi memenuhi Pasal 3 dan Pasal 5 UU Paten. Sebagaimana dijelaskan dalam kedua pasal tersebut diatas maka suatu invensi dapat diberikan perlindungan jika sudah memenuhi syarat substantif dari paten itu sendiri yaitu ketika invensi tersebut diajukan permohonan pendaftaran paten, invensi tersebut harus tidak ada sebelumnya atau dengan kata lain suatu paten tidak boleh lebih dahulu diungkapkan dimanapun dan dengan cara apa pun.

Berubahnya paten menjadi public domain akibat tidak membayar biaya tahunan seperti halnya diatas membuat hal ini betentangan dengan teori negara kesejahteraan yang mana dalam teori ini mengatakan bahwa "Negara wajib memberikan perlindungan bagi warga negaranya". Dalam hal dihapuskannya paten akibat tidak membayar biaya tahunan ini, menunjukkan bahwa pemerintah Indonesia tidak lagi melindungi hak inventor, yang mana hal tersebut menyebabkan seorang inventor kehilangan hak ekonomi dan hak moral yang sebelumnya dimiliki olehnya. 


\section{Perlindungan terhadap inventor terkait unsur kebaruan paten yang hapus akibat tidak membayar biaya tahunan}

Moza Ramadhani, Muhammad Amirulloh, Pupung Faisal

Selain itu juga hal tersebut menunjukkan bahwa pemerintah tidak memenuhi tujuan dari negara kesejahteraan itu sendiri yaitu bertanggung jawab atas kesejahteraan. Selain itu berubahnya paten menjadi public domain akibat tidak membayar biaya tahunan juga betentangan dengan Prinsip Alter Ego, yang menyatakan bahwa antara inventor dan invensinya merupakan satu kesatauan yang tak dapat dipisahkan. Pada prinsip ini juga menyatakan bahwa inventor berada pada kedudukan tertinggi yang hak kepemilikan atas suatu ciptaannya tidak dapat diganggu gugat, secara prinsip teori ini memberikan penghargaan yang tinggi dan melekat pada pencipta atas hasil karyanya.

Pencipta akan mendapatkan nilai tambah terhadap martabat dan keuntungan ekonominya apabila pencipta tersebut membuat HKI yang semakin beragam dan berkualitas yang mampu membantu mencerdaskan kehidupan bangsa pada umumnya (Lindsey, 2013). Dengan dihapuskannya suatu invensi dari daftar umum paten membuat inventor kehilangan hak eksklusifnya dan membuat invensi yang dimilikinya bebas digunakan oleh semua orang atau telah berubah menjadi public domain.

Paten dihapus akibat tidak membayar biaya tahunan sebagimana tercantum di dalam Pasal 130 huruf $d$, Menteri memiliki kewajiban untuk memberitahukan secara tertulis kepada inventor mengenai penghapusan yang dilakukannya dalam kurun waktu 30 (tiga puluh) hari sebelum paten dinyatakan hapus. Selain itu, paten yang telah dihapuskan juga harus dicatat dan diumumkan.

Sebagaimana diatur dalam Pasal 136 dan 137 UU Paten, dengan dihapuskannya paten akibat tidak membayar biaya tahunan mengakibatkan inventor kehilangan segala akibat hukum yang berkaitan dengan paten dan hal lain yang berasal dari paten yang dimilikinya hal tersebut membuat pemegang paten dan penerima lisensi tidak lagi memiliki kewajiban untuk membayar biaya tahunan. Penghapusan paten itu sendiri sebagaimana diatur di dalam pasal 138 ayat (1) dimulai sejak putusan penghapusan yang dikeluarkan oleh pengadilan niaga mempuanyai kekuatan hukum tetap (inkracht), yang mana hal ini termasuk juga untuk inventor yang menggugat penghapusan paten yang telah dilakukan oleh Direktorat PDTLST dan Rahasia Dagang terhadap invensi yang dimilikinya.

Mengenai unsur kebaruan suatu invensi itu sendiri (novelty) merupakan salah satu syarat substantif yang harus dipenuhi jika suatu invensi ingin mendapatkan perlindungan hak paten. Suatu invensi dapat dikatakan memiliki unsur kebaruan (novelty) apabila pada tanggal penerimaan invensi tersebut tidak sama dengan teknologI yang telah diungkap sebelumnya (teknologi terdahulu) (Dian, 2013). Hal ini menunjukkan bahwa paten yang berstatus hapus akibat tidak membayar biaya tahunan berdasarkan UU Paten dianggap tidak lagi memiliki unsur kebaruan, karena paten tersebut sebelumnya telah mendapatkan perlindungan hak paten dan berada di daftar umum paten. Invensi tersebut sebelumnya telah mendapatkan perlindungan hukum yang mana kemudian berubah menjadi public domain akibat tidak membayar biaya tahunan pemeliharaan paten.

Dihapuskannya paten akibat tidak membayar biaya tahunan juga bertentangan dengan teori perlindungan HKI yang dikemukakan oleh Robert M Sherwood, yaitu Reward Theory (penghargaan). Jika dilihat dari teori ini maka dihapuskannya paten akibat tidak membayar biaya tahunan mengakibatkan inventor tidak lagi mendapatkan suatu penghargaan sebagai imbalan atas upaya-upaya kreatifnya dalam menemukan atau menciptakan karya-karya intelektual tersebut (Ranti, 2004). Hal tersebut diakibatkan karena invensi yang sebelumnya dimiliki oleh inventor sudah tidak lagi menjadi haknya atau dapat diakatakan bahwa inventor telah kehilangan hak eksklusif yang sebelumnya dimilikinya.

Teori diatas juga sejalan dengan Recovery Theory yang menyatakan bahwa inventor seharus- 
nya memperoleh kembali apa yang telah dikeluarkannya, tetapi dengan hilangnya hak eksklusif yang sebelumnya dimiliki oleh inventor mengakibatkan inventor tidak lagi memiliki hak untuk melarang pihak lain dalam menggunakan invensinya dan juga tidak lagi mendapatkan royalti yang seharusnya diterimanya. Selain itu, 2 (dua) teori diatas juga sejalan dengan Incentive Theory. Dimana teori ini menunjukan bahwa dengan dihapuskannya paten akibat tidak membayar biaya tahunan menyebabkan tidak dilindunginya kreativitas yang dihasilkaan oleh para inventor, dimana seharusnya inventor dapat menciptakan invensiinvensi baru yang memiliki kemanfaatan bagi negara Indonesia.

Selanjutnya jika kita melihat pada Risk Theory, dengan dihapuskannya paten menunjukkan bahwa invensi yang sebelumnya telah mendapatkan perlindungan hukum tidak lagi dilindungi. Inventor yang sebelumnya memiliki hak untuk melakukan monopoli terhadap invensi yang dimilikinya dalam jangka waktu tertentu menjadi kehilangan hak untuk melakukan hal tersebut, karena invensi yang sebelumnya dimilikinya telah berubah menjadi public domain dan sudah secara bebas diganakan oleh semua orang tanpa harus membayar paten kepada inventor yang memiliki invensi.

Jika kita mengacu pada "economic growth stimulus", atau "social rate of return" yang mana inti dari teori ini mengakui bahwa pelindungan atas HKI adalah suatu alat dari pembangunan ekonomi. Pembangunan ekonomi itu sendiri merupakan keseluruhan tujuan dari dibangunnya suatu sistem pelindungan atas sistem pelindungan atas HKI yang efektif (Yoga, 2018). Maka dengan diberikannya perlindungan terhadap paten menunjukkan bahwa adanya pembangunan ekonomi yang ditunjukkan dengan inventor yang bisa mendapatkan royalti dari suatu invensi yang dimilikinya. Tetapi dengan dihapuskannya suatu paten akibat tidak membayar biaya tahunan menunjukkan bahwa tidak terdapatnya pelindungan paten yang sebelumnya telah dimiliki oleh seorang inventor. Seharusnya paten yang telah dilindungi tidak dapat semerta- merta dihapuskan, karena Hak Paten yang telah dimiliki oleh inventor merupakan hal yang bersifat subtantif dan mengenai biaya tahunan tersebut merupakan hal yang bersifat administratif, yang mana hal yang bersifat administratif tersebut tidak dapat menghapuskan hal yang bersifat subtantif.

Tindakan hukum yang sebaiknya dilakukan oleh pemilik paten yang berstatus hapus akibat membayar biaya tahunan untuk memperoleh paten kembali. Tindakan hukum yang dimaksud disini ialah perbuatan yang seharusnya dilakukan oleh pemilik paten ketika paten yang dimilikinya dihapuskan akibat tidak membayar biaya tahunan. Perbuatan hukum menurut R. Soeroso adalah setiap perbuatan manusia yang dilakukan dengan sengaja untuk menimbulkan hak dan kewajiban. Perbuatan hukum adalah setiap perbuatan subjek hukum (manusia atau badan hukum) yang akibatnya diatur oleh hukum, karena akibat itu bisa dianggap sebagai kehendak dari yang melakukan hukum (Soeroso, 2011). Pemilik paten atau inventor dapat melakukan beberapa tindakan hukum yang sebaiknya dilakukan untuk dapat memperoleh paten miliknya kembali yang dihapus akibat tidak membayar biaya tahunan.

Pertama, pemilik paten atau inventor dapat mengajukan gugatan ke Pengadilan Niaga. Terjadinya sengketa akibat pelanggaran hukum terhadap hak inventor atau pemegang paten perlu diselesaikan sesuai dengan prosedur hukum yang berlaku untuk memberikan jaminan perlindungan hukum dan keadilan kepada pemegang paten. Apabila sengketa atas pelanggaran hak pemegang paten tidak diselesaikan secara hukum, maka akan menurunkan semangat dan motivasi dalam berkarya untuk menghasilkan invensi yang baru, baik untuk hasil produksi maupun proses produksi. Penyelesaian sengketa yang bersangkutan dengan bidang paten diatur dalam UU Paten itu 


\section{Perlindungan terhadap inventor terkait unsur kebaruan paten yang hapus akibat tidak membayar biaya tahunan}

Moza Ramadhani, Muhammad Amirulloh, Pupung Faisal

sendiri tepatnya pada Pasal 142. Proses penyelesaian sengketa paten dilakukan dengan melihat materi yang diajukan para pihak yang berbunyi, "sengketa pemberian paten, yaitu pemberitan paten oleh Direktorat Jenderal ternyata diberikan kepada pihak lain selain dari yang berhak, maka yang berhak dapat mengajukan gugatan" dan "sengketa atas hak ekslusif pemegang paten, yaitu menyangkut perbuatan pihak yang ternyata tidak berhak atau tidak mendapatkan persetujuan dari pemegang paten, melakukan perbuatan: membuat, menggunakan, menjual, mengimpor, menyewakan, menyerahkan atau menyediakan untuk dijual atau disewakan atau diserahkan produk yang diberi paten untuk membuat barang".

Pasal 142 UU Paten dijelaskan bahwa pihak yang berhak memperoleh paten dapat menggugat ke Pengadilan Niaga. Kedudukan pengadilan niaga sebagai pengadilan khusus di lingkungan peradilan umum memiliki kewenangan yakni menyelesaikan sengketa dalam perkara yang berhubungan dengan pelanggaran hukum di bidang paten. Gugatan atas pelanggaran di bidang paten diajukan kepada ketua Pengadilan Niaga dan juga sesuai dengan tata cara mengajukan gugatan. Dalam UU Paten juga telah mengatur prosedur dan batas waktu dalam tahapan penyelesaian perkara untuk mempercepat proses penyelesaian sengketa. Tata cara mengajukan gugatan atas pelanggaran hukum di bidang paten ke Pengadilan Niaga dan upaya hukum kasasi ke Mahkamah Agung merupakan salah satu cara pemerintah untuk memberikan kepastian hukum bagi pemegang paten yang merasa hak serta kepentingannya telah dirugikan atas perbuatan pihak-pihak lain.

Pasal 144 dan 145 UU Paten juga mengatur mengenai tata cara mengajukan gugatan, yang mana dalam uraian pasal tersebut menjelaskan kedudukan pengadilan niaga sebagai pengadilan khusus memiliki kewenangan untuk menyelesaikan gugatan ganti rugi oleh pihak pemegang paten atau penerima lisensi jika terdapat pihak lain yang menyebabkan kerugian terhadap pemegang paten atau penerima lisensi, baik dalam hasil produksi maupun dalam proses produksi.

Sebagaimana diatur di dalam Pasal 134 ayat (2) UU Paten mengatur bahwa penghapusan paten dengan alasan sebagimana telah diatur di dalam Pasal 134 ayat (1) harus diberitahukan kepada Pemegang Paten dalam jangka waktu 30 (tiga puluh) hari sebelum Paten dinyatakan hapus. Selain itu dalam UU Paten tidak mengatur bahwa pemberitahuan yang dilakukan oleh Direktorat PDTLST dan Rahasia Dagang dapat dilakukan secara elektronik dengan hanya mengunggah Surat edaran di website resmi Direktorat PDTLST dan Rahasia Dagang, sehingga pemberitahuan yang dilakukan oleh Direktorat PDTLST dan Rahasia Dagang bukan merupakan suatu bentuk pemberitahuan sebagaimana dimaksud dalam Pasal 134 ayat (2) UU Paten tersebut.

Kedua, Memperbaharui invensi yang dimilikinya sebelumnya agar memiliki perbedaan dan juga memiliki kemanfaatan yang berbeda. Memperbaharui invensi yang telah dimiliki sebelumnya agar dapat memiliki patennya kembali merupakan hal yang dapat dilakukan oleh inventor karena, jika suatu paten sudah dihapuskan dari daftar umum paten akibat tidak membayar biaya tahunan maka paten tersebut sudah dianggap sebagai public domain yang mana setiap orang berhak secara bebas menggunakan paten tersebut tanpa harus membayar paten itu kembali. Dalam hal ini inventor akan kehilangan hak ekonominya, namun hak moralnya akan tetap melekat. Kondisi seperti ini akan memberikan nilai tambah berupa akses terhadap informasi pengetahuan teknis yang bisa diakses siapapun serta menjadi peluang bagi calon inventor yang ingin mengembangkan ide dari paten yang telah menjadi public domain. Potensi pemanfaatan paten yang sifatnya public domain (freedom to operate) saat ini menjadi peluang yang sangat strategis dalam upaya pengembangan dari paten yang telah ada sebelumnya (Tommy, 2019). 
Memperbaharui invensi yang telah ada sebelumnya juga bertujuan agar invensi tersebut dapat dilindungi sebagai paten yang mana suatu paten akan diberikan jika suatu invensi mengandung langkah pembaruan serta dapat diterapkan dalam industri. Ide tersebut juga harus mengandung unsur kebaruan atau novelty.

Ketentuan Pasal 130 kurang berpihak kepada inventor atau kurang melindungi inventor yang beritikad baik dan memiliki kendala dalam masalah finansial. Pasal 128 UU Paten dijelaskan bahwa pemegang paten dapat melakukan penundaan pembayaran biaya tahunan dengan waktu 12 (dua belas) bulan terhitung sejak tanggal berakhirnya batas waktu pembayaran biaya tahunan dan setelah itu harus melakukan pembayan biaya tahunan ditambah dengan biaya tambahan sebesar $100 \%$ (seratus persen) dihitung dari total pembayaran biaya tahunan, yang mana hal ini membuat pemegang paten lebih terbebani karena harus membayar biaya pemeliharaan paten yang justru bertambah banyak dan bukan mengurangi beban biaya tahunan yang harus dibayarkan oleh pemegang paten atau inventor.

Tindakan hukum lain yang dapat dilakukan oleh inventor agar dapat memperoleh patennya kembali menurut pendapat saya adalah dengan memohon ke DJKI untuk mencarikan penerima lisensi wajib, yang mana dalam hal ini DJKI tidak hanya menjadi pencatat saja tetapi DJKI juga berperan sebagai pencari lisensi wajib agar inventor mendaptkan pemasukan dari invensi yang dilisensikan.

\section{Simpulan}

Berdasarkan analisis dan uraian di atas, terdapat dua kesimpulan. Pertama, Kedudukan unsur kebaruan dalam paten yang telah dihapus akibat tidak dibayarnya biaya tahunan sebagaimana diatur dalam Pasal 130 UU Paten menunjukan bahwa inventor telah kehilangan segala akibat hukum yang berkaitan dengan Paten tersebut sebagaimana diatur dalam Pasal 137 UU Paten. Pada prinsipnya inventor telah kehilangan unsur kebaruannya karena suatu paten yang telah dihapuskan dari daftar umum paten tersebut dianggap sudah menjadi public domain dan siapapun bebas untuk menggunakannya. Hal tersebut menunjukan bahwa invensi tersebut dianggap bukan sebagai invensi yang baru.

Kedua, Inventor yang patennya dihapuskan akibat tidak membayar biaya tahunan dapat melakukan 2 (dua) cara agar dapat memperoleh patennya kembali, yaitu pertama dengan cara mengajukan gugatan ke Pengadilan Niaga jika inventor merasa hak yang dimilikinya tidak dipenuhi dengan baik oleh Direktorat Jenderal Kekayaan Intelektual sebagaimana diatur di dalam Pasal 72 ayat (1) UU Paten yang mana tata cara gugatannya telah diatur di dalam Pasal 144 UU Paten, dan cara yang kedua adalah memperbaharui invensi yang telah dimiliki sebelumnya dengan mengembangkan produk atau proses yang telah ada sebelumnya agar inventor dapat memiliki patennya kembali.

\section{Daftar pustaka}

Amirulloh, Muhamad et. al. 2016. Buku Ajar Hukum Kekayaan Intelektual. Cet. 1. Unpad Press. Bandung.

Ganindha, R., \& Sukarmi, S. 2020. Peran pemerintah daerah dalam mendukung potensi indikiasi geografis produk pertanian. Jurnal Cakrawala Hukum, 11(2), 211-221. doi:10.26905/ idjch.v11i2.3970.

Hendrix, Tommy. 2019. Pemanfaatan Paten Public Domain untuk Daya Saing Industri (Studi Paten Pupuk Organik). Jurnal Ilmiah Manajemen Forkamma, Vol. 3, No. 1.

Mahardhita, Yoga. 2018. Perlindungan Hukum Hak Kekayaan Intelektual Melalui Mekanisme "Cross Border Measure". Jurnal Ilmiah Ilmu Hukumm QISTIE, Vol. 11 No. 1 Mei.

Mardiana, H., Amirulloh, M., \& Faisal, P. 2020. Hak paten sebagai objek jaminan fidusia berdasarkan 


\section{Perlindungan terhadap inventor terkait unsur kebaruan paten yang hapus akibat tidak membayar biaya tahunan}

Moza Ramadhani, Muhammad Amirulloh, Pupung Faisal

peraturan perundang-undangan mengenai jaminan fidusia dan paten. Jurnal Cakrawala Hukum, 11(2), 177-186. doi:10.26905/ idjch.v11i2.4094.

Mayana, Ranti Fauza. 2004. Perlindungan Desain Industri di Indonesia Dalam Era Perdagangan Bebas. Gramedia Widia Sarana Indonesia. Jakarta.

Nurfitri, Dian \& Rani Nuradi. 2013. Pengantar Hukum Paten Indonesia. Alumni. Jakarta.

Saidin, OK. 2010. Aspek Hukum Hak Kekayaan Intelektual. Rara Grafindo Persada. Jakarta.
Soeroso, R. 2011. Pengantar Ilmu Hukum. Sinar Grafika. Jakarta.

Subroto, Muhammad Ahkam. 2005. Eksplorasi Konsep Kekayaan Intelektual Untuk Penumbuhan Inovasi. LIPI Press. Jakarta.

Syahmin, AK. 2007. Hukum Dagang Internasional: Dalam Kerangka Studi Analitis. Raja Grafindo Persada. Jakarta.

Lindsey, Tim., et. al. 2013. Hak Kekayaan Intelektual. Alumni. Bandung. 